\title{
Explaining Deviations From NAV In UK Property Companies: Rationality And Sentimentality
}

First Draft, 15th June 2005

\author{
Giacomo Morri \\ Corporate Finance and Real Estate Department \\ SDA Bocconi \\ via Bocconi 8, Milan, 20136 \\ Italy \\ giacomo.morri@sdabocconi.it
}

\section{Patrick McAllister and Charles Ward}

Department of Real Estate \& Planning

School of Business

The University of Reading

Whiteknights, Reading, RG6 6AW

United Kingdom

p.m.mcallister@rdg.ac.uk

c.w.r.ward@rdg.ac.uk

Presented at the

$12^{\text {th }}$ ERES Annual Meeting

June 15 -18, 2005

Dublin

KEY WORDS: NAV, Net Asset Value, Discount, Property Company, Price Equilibrium 


\section{ABSTRACT}

One of the most vexing issues for analysts and managers of property companies across Europe has been the existence and persistence of deviations of Net Asset Values of property companies from their market capitalisation. The issue has clear links to similar discounts and premiums in closed-end funds. The closed end fund puzzle is regarded as an important unsolved problem in financial economics undermining theories of market efficiency and the Law of One Price. Consequently, it has generated a huge body of research. Although it can be tempting to focus on the particular inefficiencies of real estate markets in attempting to explain deviations from $\mathrm{NAV}$, the closed end fund discount puzzle indicates that divergences between underlying asset values and market capitalisation are not a 'pure' real estate phenomenon. When examining potential explanations, two recurring factors stand out in the closed end fund literature as often undermining the economic rationale for a discount - the existence of premiums and cross-sectional and periodic fluctuations in the level of discount/premium. These need to be borne in mind when considering potential explanations for real estate markets.

There are two approaches to investigating the discount to net asset value in closed-end funds: the 'rational' approach and the 'noise trader' or 'sentiment' approach. The 'rational' approach hypothesizes the discount to net asset value as being the result of company specific factors relating to such factors as management quality, tax liability and the type of stocks held by the fund. Despite the intuitive appeal of the 'rational' approach to closed-end fund discounts the studies have not successfully explained the variance in closed-end fund discounts or why the discount to net asset value in closedend funds varies so much over time. The variation over time in the average sector discount is not only a feature of closed-end funds but also property companies.

This paper analyses changes in the deviations from NAV for UK property companies between 2000 and 2003. The paper present a new way to study the phenomenon 'cleaning' the gearing effect by introducing a new way of calculating the discount itself. We call it “ungeared discount”. It is calculated by assuming that a firm issues new equity to repurchase outstanding debt without any variation on asset side. In this 
way discount does not depend on an accounting effect and the analysis should better explain the effect of other independent variables. 


\section{Introduction}

One of the most vexing issues for analysts and managers of real estate companies has been the existence and persistence of deviations of Net Asset Values of real estate companies from their market capitalisation. The issue has clear links to similar discounts and premiums in closed-end funds. The closed end fund puzzle is regarded as an important unsolved problem in financial economics undermining theories of market efficiency and the Law of One Price. Consequently, it has generated a huge body of research. Although it can be tempting to focus on the particular inefficiencies of real estate markets in attempting to explain deviations from NAV, the closed end fund discount puzzle indicates that deviations between underlying asset values and market capitalisation are by no means a real estate phenomenon.

Real estate companies typically have their real estate investment assets appraised annually by external consultants and the current aggregate value of the investment stock is shown in each company's Annual Report and Accounts ${ }^{1}$. Real estate companies thus provide, on an annual basis, an estimate of their total and net asset value. Due to this fact, it has long been recognized that the market capitalization of real estate companies varies from their stated net asset values. This topic has generated a body of research which has mainly investigated the cross-sectional differences in NAV deviation between companies. However, as we shall see below, explanatory models of cross-sectional variations in NAV deviation tend to have weak explanatory power ${ }^{2}$.

An often overlooked point is that there is a strong case for arguing that we should expect a priori a deviation between NAV and market capitalization. By investing in publicly traded collective real estate vehicles rather than directly acquiring real estate assets, the investor is investing in a vehicle which has different investment qualities than ownership of the underlying assets. Compared to direct ownership, there are major differences in terms of liquidity, trading and price formation, financial structuring, search costs, management control, lot size, taxation and transaction costs inter alia. Given these differences it would be surprising if NAV mirrored the market capitalization. Perhaps the enigma is that whilst real estate securities appear to be

\footnotetext{
${ }^{1}$ Trading assets are held at the lower of cost and net realizable value.

${ }^{2}$ In a number of studies, adding the average sector discount to a model improves the explanatory power. However, although this indicates that there common are factors causing deviations from NAV, NAV deviations are essentially being explained by the common NAV deviation. This leaves the question of the cause of the common NAV deviation.
} 
superior in terms of the qualities outlined above, they often tend to trade at discounts rather than premiums.

Before discussing explanatory models of the discount to NAV below, we address some important methodological issues. As we shall note, the potential effect of a variable on the discount to NAV - discounts rather than premiums have typically been the focus of much research - is not always self-evident. For some of the variables cited below, it is possible to generate plausible arguments for a variable to cause both a positive and negative deviation from NAV. Further, variables may change in their implications depending upon market conditions. For instance, the market perception of high gearing may be favorable when asset values are expected to increase or interest rates are expected to decrease. On the other hand, when the opposite holds the market perception of high gearing may be unfavorable ${ }^{3}$. Further, previous studies have found that portmanteau variables such as volatility or dividend yield have significant explanatory power. However, such variables are more likely to be a consequence of the same underlying causes of NAV deviation. Finally, it is also important to distinguish clearly between factors that explain cross-sectional variations in deviation from NAV between companies and changes in a sector's deviation from NAV over time. Essentially complete explanations need to be able to explain:

i. cross-sectional variation in deviations from NAV at a given point in time,

ii. the existence of premiums to NAV and

iii. fluctuations in the level of sector deviation from NAV over time.

There have been two approaches to investigating the discount to net asset value in closed-end funds: the 'rational' approach and the 'noise trader' or 'sentiment' approach. The 'rational' approach hypothesizes the discount to net asset value as being the result of company specific factors relating to such factors as management quality, tax liability and the type of stocks held by the fund. Despite the intuitive appeal of the 'rational' approach to closed-end fund discounts the studies have not successfully explained the variance in closed-end fund discounts or why the discount to net asset value in closed-end funds varies so much over time.

\footnotetext{
${ }^{3}$ For instance Clayton and McKinnon (2000) find that debt to equity ratio has significant explanatory power in the 'downturn' and is insignificant in the 'upswing' for US REITs
} 
The second approach, which is generally described as the 'noise trader' model is associated with the work of Shiller (1989), De Long, Shleifer Summers and Waldmann (1990) and Shleifer and Vishny (1990). The model is conceptually complex and posits the existence of two types of investors operating in the market; the rational and the noise traders. In essence, the operation of the noise traders provides an additional risk that is reflected in the value and returns of stocks. Not only does the noise trader model predict that security prices will diverge from fundamental values in the short run but that securities will be priced below fundamental values in equilibrium. The 'noise trader' approach has been applied to closed-end fund discounts by Lee, Shleifer and Thaler (1991) with some success.

\section{The Rational Explanations}

\section{Unrealized Capital Gains Tax}

Closed-end fund net asset values are based of the market value of the securities they hold $^{4}$. If a fund holds securities that have appreciated, the sale of these securities would incur capital gains tax. Thus, the net asset value is not necessarily what shareholders would realize in the event of a fund being liquidated. In principle, the same argument can be applied to real estate companies. Many real estate investment companies have substantial unrealized reserves as part of their capital due to the upward movement in the value of their assets. Revenue from the sale of this property would be subject to taxation. Adams and Venmore-Rowland (1989) show that a reduction in contingent tax liability in the 1980s, due to changes in tax legislation, may have had led to some small reduction in individual real estate company discounts. However, they also show that substantial discounts exist even when posttax NAVs are calculated. Although Barkham and Ward (1999) do find that capital gains tax liability and size are statistically significant explanatory variables, the explanatory power was weak. Indeed there are a number of fundamental limitations to it as explanatory variable Dimson and Minio-Paluello (2002) point that the tax liability theory implies that on open-ending the NAV should decrease whilst in reality prices rise to NAV. They further point out that, in a rising market, increasing tax liabilities should widen the discount. Empirically there is little relationship. Crucially,

\footnotetext{
${ }^{4}$ Management of closed-end funds is obliged to publish the market value of the securities they hold.
} 
unrealized capital gains tax liabilities can only explain a discount to NAV whilst we have been able to observe premiums to NAV in real estate and mutual funds. Finally, and most obviously, whilst US REITS are not subject to capital gains tax, they do experience substantial deviations from NAV.

\section{Agency Costs - Insider ownership and Management Expenses}

High expenses represent dead-weight losses to the investor and might be expected to be correlated with high discounts. Historically, real estate companies in the UK have attracted considerable criticism from fund managers because their management expenses are alleged to be excessive. In the US, Capozza and Lee (1996) find some evidence that REIT discounts are correlated with expense ratios. In the closed end fund literature, Gemmill and Thomas (2002) find that higher management expense also contribute to a larger discount, although the relationship is masked by the collinearity of expenses with age of fund and cost of arbitrage.

Malkiel argues that insider ownership may increase the discount because it reduces the likelihood that a fund will be taken over and liquidated at the net asset value. Real estate companies are frequently taken over by other companies but are rarely taken over in order to be liquidated. However insider ownership may reduce the prospect of a take-over bid being launched, the opportunity for profitable arbitrage and therefore widen the discount. On the other hand, if the directors of the company are important shareholders there is less likelihood of conflicts of interest between the non-directorial shareholders and the management. This would suggest lower discounts in firms with high insider ownership.

\section{Reputation}

Malkiel (1995) argues that a history of good performance may result in a management gaining a 'premium rating'. Adams and Venmore-Rowland also assert that the market capitalization, and therefore the discount, is affected by the market's perception of the entrepreneurial ability of the company's management. It is very difficult to measure this type of factor but Malkiel (1995) suggests that some measure of achieved returns might be used as a proxy variable. An alternative approach to measuring manager reputation may be the proportion of manager remuneration that can is due to a performance bonus. This tends to contradict the 'expensive management' argument. Essentially the argument is that good performing managers tend to be expensive. 
Size

When reporting their financial position, real estate companies have each individual property appraised at the market value. If a company was forced to sell its entire stock, it could lead to a considerable addition to the normal flow of real estate in the market. Thus, the aggregate value of a company's assets is not necessarily the sum of the values of the individual properties. It can be hypothesized that companies with larger holdings would face greater illiquidity and they would therefore have larger discounts. However size might affect discount in some other ways. Adams and Venmore-Rowland argue that for high value properties, access to capital acts as a barrier to entry into the market. They argue, along with Gau (1987) that restricted competition leads to the inefficient pricing of high value properties and to opportunities for larger institutions, with access to capital, to earn abnormal returns from the larger properties.

In common with Barkham and Ward (1999) and Clayton and McKinnon (2001), Anderson, Conner and Liang (2001) in a cross-sectional study of NAV dispersion in 2000 report that large REITs tend to have lower discounts. Although Capozza and Lee (1996) also find that small REITs have the largest discounts, they also find that small REITs appear to have the highest expense ratios and these two effects are not disentangled. Anderson et al (2001) speculate that the size effect is due to higher liquidity, better access to capital markets and economies of scale. They also suggest that there may be an upper limit when, for diversified funds, a conglomerate effect may emerge. This may be significant in the UK, where there is anecdotal evidence to suggest that large real estate companies that do not specialize may be penalized by large discounts.

\section{Leverage}

Debt can have an affect on the discount to NAV by virtue of the way in which the discount is calculated. For instance, a firm with no debt, book assets of $\$ 100$ and shares valued at $\$ 80$ in the market might have a discount of $20 \%$. If the firm issues $\$ 40$ of debt to repurchase $\$ 40$ of equity, the book value of net assets will fall to $\$ 60$ but the market value of shares, ceteris paribus, will be $\$ 40$ and the discount will increase to $33 \%$. 
Studies have tended to find that companies with high levels of leverage tend to have the higher discounts to NAV. Anderson et al $(2000,4)$ argue that

"Higher leverage reduces financial and strategic flexibility, increases sensitivity to changes in market conditions and interest rates, and increases the volatility of earnings, all of which are penalized in the public REIT market."

As noted above, Clayton and McKinnon (2000) and Bond and Shilling (2003) have found that leverage is significant explanatory variable in some model specifications. Bond and Shilling (2003) examine the role of volatility as well as conventional factors in explaining discount to Net Asset Value discounts across a sample of European real estate companies. They find that there is a strong positive relationship between total volatility and the discount to NAV. The only statistically significant 'rational' explanatory variable is leverage suggesting that the two variables are (as expected) linked. However, even this finding changes when volatility is added to the model. They find evidence that both systematic and unsystematic risk is associated with increases in discount to NAV.

\section{Accounting Issues}

It was stated above that some real estate companies undertake real estate trading. Real estate designated for trading is held in the balance sheet at the lower of cost or market value. This implies that trading stock will never be shown in the accounts above its market value but it might sometimes be below it. If assets are recorded below their market value, the calculated NAV and therefore the discount will be reduced. Although the sample of companies included in this study have relatively small amounts of trading stock in their Balance Sheets, we include a variable that controls for this factor.

\section{Appraisal Smoothing}

A potential explanation for the deviations from NAV in the real estate market that is does not apply for closed end equity funds is mis-estimation of the values of the assets. For real estate both the appraisals and the market capitalization can be wrong. Noise theory implies mis-estimation of fundamental value by noise traders. However, as noted above, the processes by which prices are formed in the capital markets and appraisals are formed in real estate markets are different. The limitations of real estate 
appraisals have been extremely well-documented (see Baum et al. 2002 for a full discussion). Essentially due to sluggish or smoothed responses to 'news', it is commonly held that valuations tend to underestimate the extent of changes in market values and tend to lag changes in market values. It has been convincingly documented that so-called appraisal smoothing is a rational process given the information uncertainties in the appraisal process (see Quan and Quigley, 1991). In contrast, assuming active markets, 'news' is incorporated in equity prices instantaneously. As a result, deviations may be partially explained by differences in timing of response to changing expectations by asset valuations compared to real estate share prices. This may help to explain both premium and discounts to NAV. This also generates an $a$ priori expectation that, in line with the price discovery literature, changes in NAV discounts/premiums should provide a leading indicator of the recorded performance of private markets. It is not surprising that Gentry, Jones and Myer (2004) find that deviations from NAV have some predictive power for future NAV growth. Additionally Barkham and Ward (1999) found that changes in property share prices 'Granger caused' changes in net asset values.

\section{Market Segmentation}

In real estate the long-term co-integration between private and public share markets is a well-established stylized fact. However, an interesting finding in studies of international closed end country funds is that prices of such funds are sometimes more closely related to the performance of investors' domestic markets rather than the specific country (see Chang et al, 1995 and Bailey and Lim, 1992). This relates closely to the discussion of sentiment effects below. In real estate one hypothesis is that differences in clientele between trading environments can produce dislocations in pricing between private and public real estate markets. We would expect then that when private markets significantly outperform public markets, discounts should increase and vice versa. Another aspect of market segmentation is country effects on NAV deviations. In their study of European property companies, Bond and Shilling (2003) report national variations in the level of NAV deviation. Country dummies are significant for France and Benelux. They speculatively attribute lower discounts to NAV these countries to the actual or imminent existence of tax exempt vehicles in these markets. However, they may also be due to market segmentation. 
Recently Gemmill and Thomas (2002) provide a number of insights into the closed end discount puzzle which are associated with market segmentation. They hypothesize that it is as a function of arbitrage bounds and find that funds that are difficult to replicate tend to have higher discounts. If we regard real estate companies as special cases of closed end funds, the replication problems are practically insurmountable. In essence, in real estate markets since rational investors are less able to exploit the discrepancy between the asset values and share prices, there is potential for larger discounts. However, replication risk would not explain variations in deviations from NAV over time and the existence of premiums. In addition, Gemmill and Thomas find evidence to support the noise trader hypothesis. Using flows of money to mutual funds as an indicator of sentiment, they find that it is responsible for changes in the discount. However, they also find that (contrary to noise trader theory) funds with more systematic noise risk have lower discounts.

\section{Liquidity}

A commonly commended advantage of real estate shares relative to direct real estate holdings is their increased liquidity. However, as documented in Bond et al (2003), there are a number of dimensions to liquidity. Most obviously, in terms of the ability to acquire and dispose of 'product', real estate securities offer the ability to gain relatively quick entry to or exit from real estate investment markets when expectations about the performance of real estate assets have changed. When expectations of real estate become bullish, we would expect discounts to close and/or premiums to emerge as investors achieve quick access to real estate markets, are able to acquire securities and affect prices rapidly. In contrast, there are institutional obstructions to rapid market entry in the private real estate markets which delay the emergence of evidence of market re-pricing.

Delay and uncertainty in capital realization also imposes costs to investors. In the capital markets, Dimson and Hanke (2002) found that less liquid bond synthetics trade at discounts to the underlying assets despite having lower transaction costs. Looking at REITs in the period 1985-92, Benviste, Capozza and Sequin (2000) attempt to measure the gain from the increased liquidity of REITs relative to direct ownership. They estimate that securitizing direct property generates increases in value of between $12 \%$ and $22 \%$. Cross-sectional and temporal variations in liquidity both 
between and within direct and indirect real estate have been viewed as potential explanations as deviation from NAV.

Clayton and McKinnon (2000) focus on market microstructures and liquidity as the explanation of cross-sectional variations in NAV deviations. Given problems associated with interpreting volume as a measure of liquidity, they use relative effective bid-ask spread as a liquidity proxy. Focusing on changes in premiums to NAV over time, they find that a common element in REIT liquidity is related to changes in NAV deviations. They conclude that the increase in spreads associated with convergence of NAV and market capitalization is consistent with the presence of informed investors in the market and is also consistent with the noise theory of departures from NAV. Building upon the limits to arbitrage explanations, there is also a body of work from the capital markets which focuses on limitations to short selling as causes of the deviations from fundamental value. For instance, Chen, Hong and Stein (2002) and Jones and Lamont (2002) show hat when the costs of short selling are high, prices of closed end finds can deviate persistently from NAV.

\section{The Noise Trader Explanation}

The 'noise trader' approach identifies essentially, two types of capital market participants: rational and irrational. Rational market participants trade on the basis of unbiased estimates of future earnings derived from current information about fundamentals. Irrational investors, or noise traders trade not on information about fundamentals but on market sentiment. Such sentiment might be due to the advice of popular investment commentators or simple trading rules or might even emerge spontaneously. When asset prices are influenced by sentiment in efficient markets, rational investors engage in arbitrage and in so doing ensure that prices converge to the levels warranted by current information. Irrational investors can be active in efficient markets but they will have little impact on price because of arbitrage by rational investors. However the efficient market view contrasts sharply with the arguments based on noise traders (Cuthbertson, 1996). Within the noise trader view, the influence of noise traders is asserted to be pervasive and unlikely to be arbitraged away by rational investors. The reason for this is that rational investors have finite horizons and noise trader sentiment is both stochastic and systematic. 
Research on the influence of irrational market participants has been carried out by Shiller (1989; 1990) Shleifer and Vishny (1990) and Kirman (1993) However in this paper we are concerned with a model of the of the interaction of noise traders and rational investors in asset markets put forward by De Long, Shleifer, Summers and Waldmann (1990), DSSW hereafter. DSSW argue that when asset prices are forced above those warranted by fundamentals because of positive or negative noise trader sentiment, mis-pricing will not be fully arbitraged away. Three assumptions are crucial to the model.

The first assumption is that rational investors are risk averse and have finite horizons. There are four reasons why rational investors may have finite horizons. First, the performance of fund managers (rational investors) is assessed on a short term, generally quarterly, basis. Second, individuals who hold shares often have a need for liquidity. Third, if cash or assets are borrowed, the cumulative cost of the transaction increases the longer the trade. Fourth, short sales are difficult and costly in the long term. Thus, rational investors are concerned with the interim resale price of assets the unpredictability of which is exacerbated by the presence of noise traders in the market.

A second assumption of the DSSW approach is that noise trader sentiment is stochastic and cannot be predicted by rational investors. Therefore, rational investors, concerned as they are with the interim resale price of assets, have to take into account not only fundamental risk but also the risk that noise traders may have driven prices further away from fundamentals during the holding period. This risk exists even if noise traders are not, at the start of the holding period, excessively optimistic or pessimistic. Rational traders might believe that prices will return to their fundamental values in the long run but stochastic noise trader sentiment may disturb the relationship between prices and fundamentals in the interim.

A third assumption of the DSSW model is that noise trader risk, that is excess volatility and the divergence of price form fundamentals, is correlated across assets. In other words, noise trader risk is systematic. Were noise trader risk not market wide it would not be priced, for the same reason that idiosyncratic fundamental risk is not priced.

The DSSW model has a number of implications not least for the explanation of financial market anomalies. The implication that has most concern for this paper is 
that the presence of noise traders in financial markets results in a permanent deviation of price from fundamental value. This is the result of rational traders having to bear noise trader risk as well as fundamental risk. DSSW note that, in most cases it is difficult to observe this mis-pricing because it is difficult to correctly estimate fundamental values. However fundamental values can be estimated and are indeed given in the case of closed end mutual funds. DSSW thus argue that the noise trader hypothesis explains why closed end funds typically trade at a discount to NAV.

This suggestion is elaborated on and investigated by Lee, Shleifer and Thaler (1991) (hereafter LST). LST suggest that there are actually four parts to the puzzle about closed-end fund discounts and that the noise trader approach is more successful in explaining this four part puzzle than the 'rational approach'. Briefly the four part puzzle is: 1) closed end funds typically start at a premium to NAV; 2) after listing, closed-end funds move to a discount within a few months of trading; 3) the discount on closed end funds are subject to wide variation over time, and; 4) discounts shrink when fund are open ended or liquidated. To explain the four-part puzzle LST add one further assumption to the DSSW model, that of differing clienteles. LST argue that closed end fund stock is held predominately by small investors (equated by LST with noise traders) whilst the underlying assets are held mainly by institutional investors, (equated with rational investors).

The LST argument is that closed-end fund shares are subject to noise trader risk whereas the assets held by closed end funds are not. Thus closed end fund shares are riskier than closed end fund assets, have to earn a higher rate of return in equilibrium and are therefore priced below net asset value (part 2 of the puzzle). The initial premium (part 1 of the puzzle) arises from that smart investors taking advantage of noise traders by creating closed end funds at times of positive noise trader sentiment. The variation in time of the discount (part 3 of the puzzle) is due to changes in noise trader expectations. Thus, discounts to NAV are a sentiment indicator.

The LST approach can be applied directly to real estate companies. However, the additional assumption of LST that shares and assets are held by differing clienteles is worth exploring in the case of real estate companies. The logic of the model dictates that the investors who trade the assets owned by real estate companies differ from the investors who trade the shares of the real estate companies. If similar investors traded both the assets and the shares of real estate companies, the same sentiment changes would affect both and they would be equally risky. The assets held by real estate 
companies are office, retail, and industrial real estate. These types of real estate are primarily traded by professional and institutional investors. Real estate company shares provide the main vehicle by which small investors can take a position in the real estate market when sentiment is positive ${ }^{5}$.

However, Barkham and Ward (1999) tested a number of specific implications of the noise trader hypothesis. Testing the hypothesis that positive (negative) noise trader sentiment will reduce (increase) the discount to NAV over time but the discount will fluctuate around a long run average determined by the risk premium, required by rational participants for bearing noise trader risk, they developed a vector-errorcorrection model in which the restriction of cointegration is imposed ${ }^{6}$. They found that net asset values respond, but not rapidly, to movements in property shares by moving back to the equilibrium relationship. They further hypothesized that the deviation from net asset value will be correlated with other indicators of sentiment not related to real estate, for instance expectations about inflation, consumer confidence and industrial optimism. They find that consistent with the noise trader hypothesis that the MMI index of inflation expectations and the CBI index of industrial optimism are both significant influences on the discount to net asset value. In addition, Barkham and Ward (1999) found that their 'rational' model had weak explanatory power $\left(\mathrm{R}^{2}\right.$ $15 \%)$ and the inclusion of the average sector discount improved the explanatory power of the model. This provided further support for a sentiment explanation of the NAV discount. Barkham and Ward (1999) also report that, consistent with the noise trader hypothesis, national sentiment indexes have a negative relationship with the level of discount. Levels of discount will be highly correlated across funds.

In summary, previous 'economic' explanations of deviations from real Net Asset Values for real estate companies have had limited explanatory power. It is often overlooked that such deviations can be interpreted as a rational outcome of the different, particularly in terms of liquidity, characteristics of the two 'routes' into real estate investment. Whilst studies of the closed-end fund puzzle strongly suggest that it is not a 'pure' real estate phenomenon, the ways that appraisals and prices are formed in the real estate markets adds further complications. Deviations may occur because of

\footnotetext{
${ }^{5}$ Of course, more sophisticated investors can simulate property returns with a portfolio of other assets (Ward and Henry, 1995).

${ }^{6}$ This restriction, of course, is not based on an assumption of a cointegrating relationship but on the demonstration of this relationship.
} 
- Differences between price formation processes in securities markets and real estate markets

- Biased appraisal of real estate assets

- The effects of gearing

The drivers of price formation such as sentiment/noise trading in securities markets will vary over time. Additionally, for a number of variables e.g. gearing, better liquidity, the implications will create different expectations in different market conditions. As a result, explanations of deviations from NAV are likely to be inherently complex and multi-dimensional. From a modeling perspective, it should not be surprising if variables change sign or change in significance over different time periods.

\section{Data Description}

Previous studies that attempted to analyze discount to NAV in different countries have been hampered by differences in accounting and tax rules; our sample is based only on U.K. listed companies in the property sector of the London Stock Exchange. The data used in this paper comes from three different sources:

o all data from Balance Sheets and Income Statements have been collected from Hemscott and are actual for the period from 1999 to 2004;

o stock prices, volumes, dividend yields, total return and total return indexes and other Stock Market data are from DataStream Thomson Financial;

o direct property market data are from IPD (actual data) and IPF (forecast).

Several steps were involved in the identification of the sample. Initially, the sample covered all listed companies recorded in FTSE All Share Index classified by Hemscott as "Real Estate Holding \& Development”. Companies classified as “Property Agencies” have not been included. Three firms were excluded because data were not available.

Hemscott contains standardized balance sheets for U.K. companies: the data contained detailed company information on all listed properties companies in UK. The final sample is composed of 26 companies and accounts for $92 \%$ of the market capitalization of the listed real estate sector. The criterion adopted for the final subset 
of companies required every company to have four years of data available. Hence the sample is reduced to 104 observations after eliminating total returns not available on Datastream. All data refer to the end of fiscal year for each company, so discount is calculated in different periods. Details of the companies can be found in Appendix 1.

\section{De-gearing the Discount}

One important way that our study differs from previous work is that we include a different definition for discount to NAV (DISCDEF). Discount to NAV, as typically defined in the literature, is calculated on the following basis:

$$
D I S C=100 *(N A V-M C) / N A V
$$

where:

$\mathrm{NAV}=$ Net asset value

MC = Market capitalization.

The property company NAVs are estimated at the end of the fiscal year and are provided by Hemscott. Market capitalization is the total value of shares (Price * numbers of issued shares) at the end of the fiscal year (see Appendix 2 for details of inter-company variations in date of fiscal year.)

Previous studies on discount to NAV demonstrate that there is a positive correlation between debt and discount. Debt can have an effect by virtue of the way in which the discount is calculated. For instance, a firm with no debt, book assets of $£ 100$ and shares valued at $£ 80$ in the market might have a discount of $20 \%$. If the firm issues $£ 40$ of debt to repurchase $£ 40$ of equity, the book value of net assets will fall to $£ 60$ but the market value of shares, ceteris paribus, will be $£ 40$ and the discount will increase to $33 \%$. So the analysis of discounts is always affected by a gearing effect independently from its genuine relevance in explaining a deviation.

A alternative way to study the phenomenon is to 'clean' the gearing effect by introducing a new way of calculating the discount itself. We call it "ungeared discount”. It is calculated by assuming that a firm issues new equity to repurchase outstanding debt without any variation on asset side. In this way discount does not 
depend on an accounting effect and the analysis should better explain the effect of other independent variables. A simple example may better explain the rationale.

We consider a company with a market asset value equal to $£ 100$ and no debt, so NAV is equal to $£ 100$. Assuming a stock market value equal to $£ 80$ the traditional discount is:

Table 1: Illustration of Discount to NAV (No debt)

$\begin{array}{ll}\begin{array}{l}\text { market asset value (A) } \\ \text { debt value (D) }\end{array} & 100 \\ \text { NAV } & 0 \\ \text { market cap (MC) } & 100 \\ \text { discount to NAV } & 80 \\ \text { Nat } & \mathbf{2 0 \%}\end{array}$

$$
\text { DISCa }=100 *(N A V-M C) / N A V=100 *(100-80) / 100=20 \%
$$

If the company decides to issue debt of $£ 12$ (column B) and buy back equity at market value, there is no change on the asset side but a new financial structure: equity has been reduced by 12 and is now $£ 68$ and debt is equal to $£ 12$. Assuming the market does not consider any tax shield effect (further discussed below), the traditional discount (see column B in table below) will be

$$
D I S C b=100 *(N A V-M C) / N A V=100 *(88-68) / 88=22.7 \%
$$

Table 2: Illustration of Discount to NAV (with debt)

$\begin{array}{lll}\text { market asset value (A) } & \text { A } & \text { B } \\ \text { debt value (D) } & 100 & 100 \\ & 0 & 12 \\ \text { NAV } & 100 & 88 \\ \text { market cap (MC) } & 80 & 68 \\ \text { discount to NAV } & & \\ & \mathbf{2 0 \%} & \mathbf{2 2 . 7 \%}\end{array}$

We see that the discount has been reduced only through an accounting effect without any change in the asset values. This provides a partial explanation of the strong positive relationship between NAV discount and gearing. 
Our definition of "Ungeared" discount to NAV incorporates the total asset and total liability values rather than the net asset value and thus can be estimated by the following formula:

UNGDISC $=100 *[(N A V+D e b t)-(M C+D e b t)] /(N A V+D e b t)$

Rewriting

UNGDISC $=100 *(N A V-M C) /(N A V+D e b t)$

Debt $=$ Debt value as reported in the balance sheet

Table 3: Illustration of Ungeared Discount to NAV

\begin{tabular}{|c|c|c|}
\hline & $\mathbf{A}$ & $\mathbf{B}$ \\
\hline market asset value (A) & 100 & 100 \\
\hline debt value (D) & 0 & 12 \\
\hline NAV & 100 & 88 \\
\hline market cap (MC) & 80 & 68 \\
\hline discount to NAV & $20 \%$ & $23 \%$ \\
\hline enterprise value $(\mathrm{MC}+\mathrm{D})$ & 80 & 80 \\
\hline Ungeared NAV $(\mathrm{NAV}+\mathrm{D})$ & 100 & 100 \\
\hline Ungeared discount & $20 \%$ & $20 \%$ \\
\hline
\end{tabular}

In this way the financial structure does not directly affect the discount to NAV for purely accounting reasons. This new formula allows a more effective approach to evaluating the effects of other determinants of NAV discount and at the same time allows better understanding the genuine effect of the gearing structure on the level of discount.

\section{Data}

In the following part we present some basic descriptive statistics on discount to NAV (DISC) in our sample. As noted earlier, we investigate deviations from NAV for the UK listed real estate sector for the period 2000-2003. It is clear from Exhibit 1 that there has been a substantial sector discount over this period without any significant variation at the aggregate level. Although the cross-sectional variation in the discount has remained fairly stable over the four year period, it has been substantial. For 
instance, in 2003 St Mowden Properties were trading at a 37\% premium to NAV, whilst London Merchant Securities was trading at a 66\% discount to NAV.

Table 4: Discounts of UK Property Companies, 2000-2003

\begin{tabular}{|c|c|c|c|c|c|c|c|c|}
\hline $\begin{array}{r}\text { Min } \\
\text { Max } \\
\text { Average } \\
\text { Median } \\
\text { STD. Dev. } \\
\end{array}$ & $\begin{array}{c}0.05 \\
0.69 \\
\mathbf{0 . 2 9} \\
\mathbf{0 . 3 1} \\
0.16 \\
\end{array}$ & $\begin{array}{c}-0.14 \\
0.58 \\
\mathbf{0 . 2 8} \\
\mathbf{0 . 3 2} \\
0.17 \\
\end{array}$ & $\begin{array}{c}0.01 \\
0.54 \\
\mathbf{0 . 2 7} \\
\mathbf{0 . 2 7} \\
0.13 \\
\end{array}$ & $\begin{array}{c}-0.37 \\
0.66 \\
\mathbf{0 . 2 9} \\
\mathbf{0 . 2 9} \\
0.20 \\
\end{array}$ & $\begin{array}{c}-0.37 \\
0.54 \\
\mathbf{0 . 1 8} \\
\mathbf{0 . 1 7} \\
0.18 \\
\end{array}$ & $\begin{array}{c}0.16 \\
0.69 \\
\mathbf{0 . 3 9} \\
\mathbf{0 . 3 9} \\
0.12 \\
\end{array}$ & $\begin{array}{c}0.00 \\
0.60 \\
\mathbf{0 . 2 8} \\
\mathbf{0 . 2 8} \\
0.14 \\
\end{array}$ & $\begin{array}{c}0.02 \\
0.22 \\
\mathbf{0 . 0 8} \\
\mathbf{0 . 0 7} \\
0.05 \\
\end{array}$ \\
\hline Company & 2000 & 2001 & 2002 & 2003 & Min & Max & Average & STD. Dev. \\
\hline Ashtenne Holdings & 0.13 & 0.13 & 0.16 & 0.12 & 0.12 & 0.16 & 0.13 & 0.02 \\
\hline British Land Co & 0.40 & 0.34 & 0.35 & 0.49 & 0.34 & 0.49 & 0.39 & 0.06 \\
\hline Brixton & 0.27 & 0.32 & 0.26 & 0.13 & 0.13 & 0.32 & 0.25 & 0.07 \\
\hline Capital \& Regional & 0.36 & 0.33 & 0.27 & 0.31 & 0.27 & 0.36 & 0.32 & 0.03 \\
\hline CLS Holdings & 0.38 & 0.40 & 0.44 & 0.39 & 0.38 & 0.44 & 0.40 & 0.02 \\
\hline Derwent Valley Holdings & 0.15 & 0.35 & 0.44 & 0.17 & 0.15 & 0.44 & 0.28 & 0.12 \\
\hline Development Securities & 0.16 & 0.20 & 0.22 & 0.20 & 0.16 & 0.22 & 0.20 & 0.02 \\
\hline Freeport & 0.05 & -0.14 & 0.23 & 0.37 & -0.14 & 0.37 & 0.13 & 0.19 \\
\hline Great Portland Estates & 0.36 & 0.30 & 0.18 & 0.23 & 0.18 & 0.36 & 0.27 & 0.07 \\
\hline Hammerson & 0.34 & 0.40 & 0.36 & 0.19 & 0.19 & 0.40 & 0.32 & 0.08 \\
\hline Helical Bar & 0.09 & 0.05 & 0.01 & 0.28 & 0.01 & 0.28 & 0.11 & 0.10 \\
\hline Land Securities Group & 0.32 & 0.23 & 0.23 & 0.39 & 0.23 & 0.39 & 0.29 & 0.07 \\
\hline Liberty International & 0.39 & 0.41 & 0.34 & 0.24 & 0.24 & 0.41 & 0.35 & 0.07 \\
\hline London Merchant Securities & 0.38 & 0.52 & 0.51 & 0.66 & 0.38 & 0.66 & 0.52 & 0.10 \\
\hline Marylebone Warwick Balfour & 0.40 & 0.44 & 0.29 & 0.48 & 0.29 & 0.48 & 0.40 & 0.07 \\
\hline Minerva & 0.19 & 0.08 & 0.26 & 0.44 & 0.08 & 0.44 & 0.24 & 0.13 \\
\hline NHP & 0.42 & 0.46 & 0.20 & 0.14 & 0.14 & 0.46 & 0.31 & 0.14 \\
\hline Pillar Property & 0.23 & 0.12 & 0.14 & 0.32 & 0.12 & 0.32 & 0.20 & 0.08 \\
\hline Quintain Estates \& Developmı & 0.46 & 0.35 & 0.29 & 0.35 & 0.29 & 0.46 & 0.36 & 0.06 \\
\hline Shaftesbury & 0.07 & 0.05 & 0.30 & 0.24 & 0.05 & 0.30 & 0.17 & 0.11 \\
\hline Slough Estates & 0.31 & 0.39 & 0.38 & 0.17 & 0.17 & 0.39 & 0.31 & 0.09 \\
\hline St Modwen Properties & 0.07 & 0.22 & 0.07 & -0.37 & -0.37 & 0.22 & 0.00 & 0.22 \\
\hline Tops Estates & 0.69 & 0.58 & 0.54 & 0.58 & 0.54 & 0.69 & 0.60 & 0.06 \\
\hline Town Centre Securities & 0.46 & 0.43 & 0.40 & 0.46 & 0.40 & 0.46 & 0.43 & 0.03 \\
\hline Warner Estate Holdings & 0.31 & 0.31 & 0.21 & 0.23 & 0.21 & 0.31 & 0.27 & 0.04 \\
\hline Workspace Group & 0.10 & 0.00 & 0.05 & 0.33 & 0.00 & 0.33 & 0.00 & 0.13 \\
\hline
\end{tabular}




\section{Research Methodology and Results}

Some of the major decisions made by researchers into the closed end fund discount concern the choice of variables, the framing of the hypotheses in unambiguous terms and the choice of statistical methods. As the discussion above suggests, there is scope for different researchers to select different subsets of explanatory variables to support diametrically opposing hypotheses. One of the tasks taken on in the present study is to reduce as much as possible the subjective bias in choosing the number and combination of explanatory variables. We therefore determined to identify in as objective a manner as possible the number of different dimensions of the variables required to explain the discounts of the selected companies. One decision we made early on was to adopt the ungeared discount as the variables we wished to explain. As the graph of the discounts in the sample period shows, the variation from one year to the next is minimized if we adopt the ungeared discount and will therefore be more likely to be explained by a constant model. As the results will show below, the result is that the model appears to be stable over the sample period and no adjustment is made for the period in which the sample accounting ratios are selected.

By using principal components, we derived scores for the sets of potential explanatory variables. Figure in the Appendix 4 illustrates the "scree" plot of the principal components. Conventionally, the researchers select the number of principal components depending on the shape of the "scree". Often there is a shape of an elbow beyond which further components contribute little explanatory power of the variability in the data. In this case however, we note two points: it is not obvious from the plot how many dimensions are required to describe the data set and in any case the important decision is not how many dimensions are represented in the data set but how complex is the data structure required to explain the variation in ungeared discounts. We therefore extracted the principal component scores and regressed the ungeared discount against successive larger number of principal component scores. After six principal components were included, there was no evidence that further data were required. (See Table 5). The F-test rejected the hypothesis that 5 principal components were adequate since plainly the sixth added significant explanation to the regression. However equally obviously, the seventh principal component did not 
improve the regression at all. In terms of our approach, we therefore decided that we were looking for up to six accounting variables that would be used in a regression on the ungeared discount.

Table 5: ANOVA Test of Regression of Principal Components

\begin{tabular}{|l|l|l|}
\hline Regression & $\begin{array}{l}\text { F-Test of smaller } \\
\text { regression }\end{array}$ & Probability \\
\hline $\begin{array}{l}\text { Ungeared Discount on 6 } \\
\text { principal components }\end{array}$ & $\begin{array}{l}\text { Against 5 variables } \\
\text { F=72.189 }\end{array}$ & 0.0000000017 \\
\hline $\begin{array}{l}\text { Ungeared Discount on 7 } \\
\text { principal components }\end{array}$ & $\begin{array}{l}\text { Against 6 variables } \\
\text { F=1.444 }\end{array}$ & 0.2367 \\
\hline
\end{tabular}

To select the variables, we eliminated some obvious pairs of variables that would cause multi-collinearity. For example there were three size variables, SIZEEV, SIZEMV and SIZETA as can be seen in scatter-matrix (Figure 1), they are highly correlated and would be likely to cause problems if included in the same regression. We therefore included only the SIZEEV variable. It should be noted that these ratios, like many accounting ratios are significantly non-normal in their distributions. Further work might be required to transform some of the accounting data into more tractable forms for the regression. 
Figure 1: Scatter matrix of Size variables
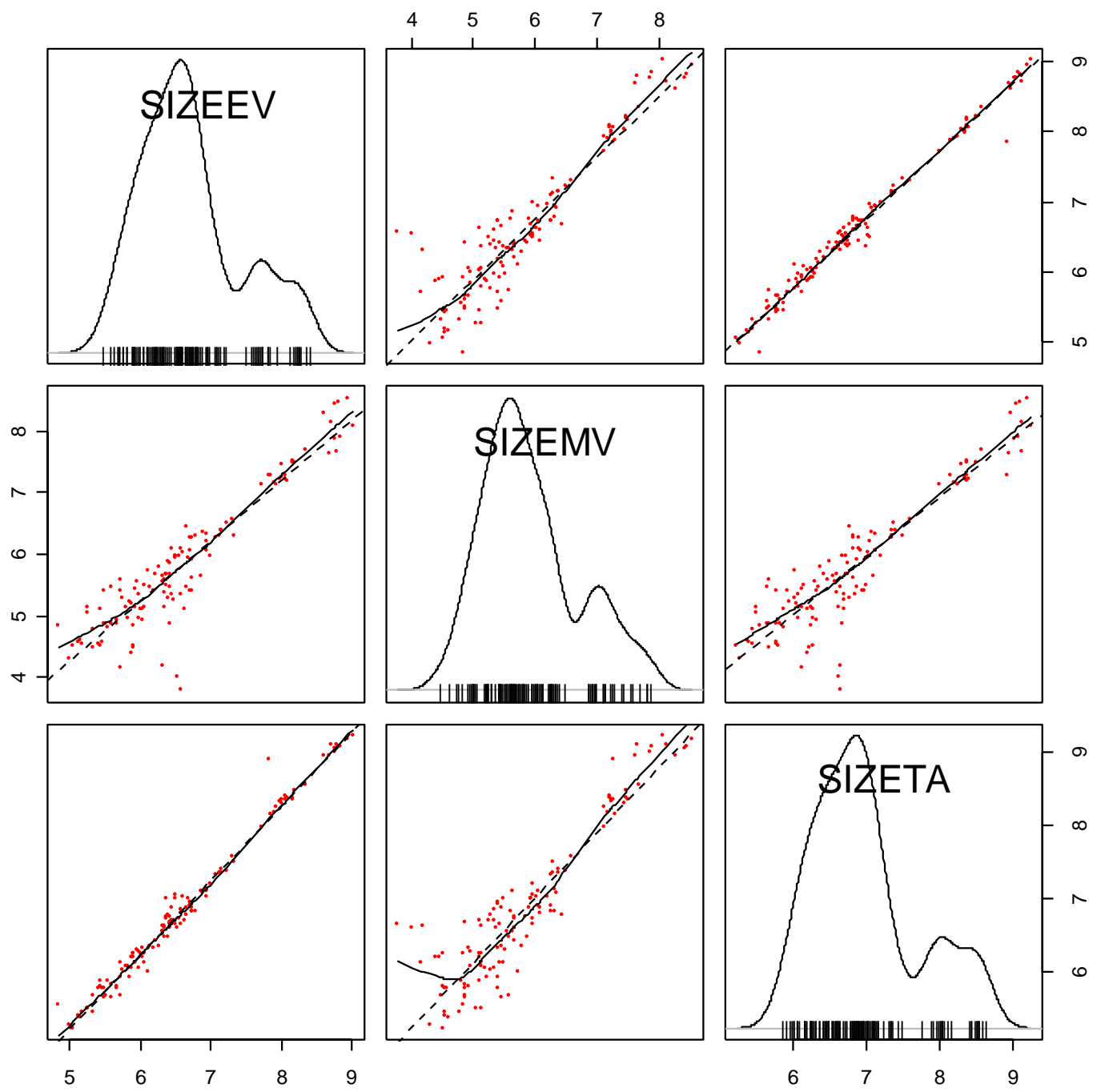

Starting from the reduced set of 49 variables we performed an all-possible subset regression, the summary of which is shown in Figure 2. 


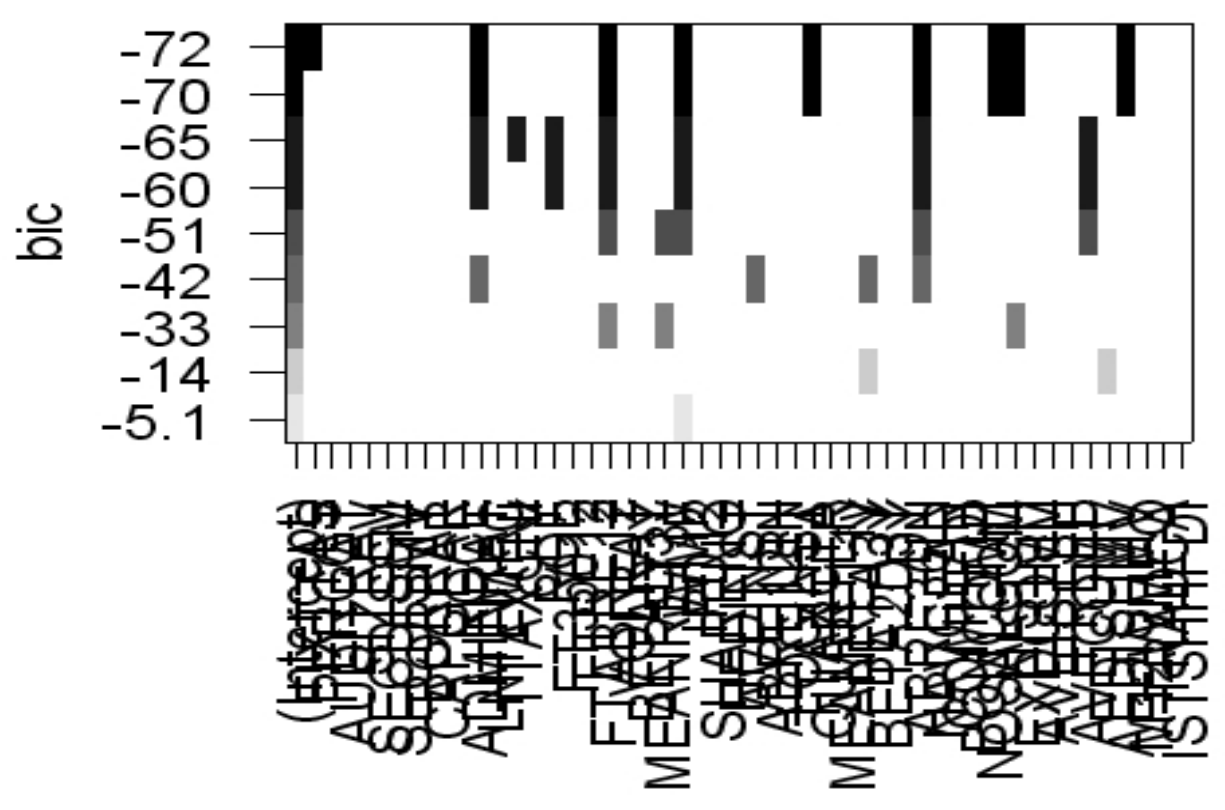

The diagram summarizes the specific variables that best contribute to the explanatory power of the regression. At the top of the diagram, there are 10 variables. As one moves downwards, the number of variables are reduced until at the bottom there is only one variable that show any explanatory power at all. The interpretation of the output from the all-possible subset regression is difficult because it correctly shows that different combinations of some variables are equally valid as other combinations. After some trial and error we selected the eight variables FIXTAS, MEANRT1Y, BET3Y, DY, NAVGEAR, ROE, LOGINST and NOSALCOM. We therefore regressed the Ungeared discount against these variables with the result shown in Table 6. 


\begin{tabular}{|c|c|c|c|c|}
\hline & Estimate & Std. Error & t value & $\operatorname{Pr}(>|t|)$ \\
\hline (Intercept) & 0.361 & 0.103 & 3.5 & $0.0007 * * *$ \\
\hline FIXTTAS & 0.124 & 0.075 & 1.65 & 0.102 \\
\hline MEANRT1Y & -0.141 & 0.026 & -5.5 & $0.00000026 * * *$ \\
\hline ВET3Y & 0.071 & 0.026 & 2.73 & $0.007 * *$ \\
\hline DY & 1.79 & 0.485 & 3.69 & $0.0003 * * *$ \\
\hline NAVGEAR & -0.048 & 0.017 & -2.78 & $0.006 * *$ \\
\hline $\mathrm{ROE}$ & -1.254 & 0.312 & -4.02 & $0.0001 * * *$ \\
\hline LOGINST & -0.023 & 0.007 & -3.2 & $0.002 * *$ \\
\hline NOSALCOM & -0.22 & 0.043 & -5.117 & $0.00000136 * * *$ \\
\hline Signif. & $\begin{array}{r}0 \\
0.01\end{array}$ & $\begin{array}{l}{ }^{*} * * * 1 \\
{ }^{*} * 1\end{array}$ & $\begin{array}{r}0.001 \\
0.05\end{array}$ & \\
\hline
\end{tabular}

Residual standard error: 0.07 on 108 degrees of freedom

Multiple R-Squared: 0.54, Adjusted R-Squared 0.51

F-statistic: 15.82 on 8 and 108 DF, p-value: 3.132e-15

Standard error: 0.5395

The results seem intuitively acceptable. An interesting variable is NOSALCOM. This represents the proportion of managers salaries that is paid by bonus. We hypothesized that companies would offer better salaries to better managers but offer rewards conditional upon performance. The coefficient here is significant at the $1 \%$ level and has the expected sign. The more that directors earn in performance related rewards, then the lower tends to be their company's discount. Gearing is also significant at the 5\% level. We noted above that we felt that gearing was an ambiguous variable and could be viewed as a positive and negative dependent upon market conditions and its level. In our sample period, an increase in gearing tends to be associated with a fall in the discount. However, it is possible that this finding could be reversed in different market conditions.

The common "portmanteau” variables also emerged as significant. In common with other studies, we found that dividend yield was significant and had the normal positive sign - the higher the dividend yield, the higher the discount. However, a high dividend yield may signal a whole raft of issues with a company. Like a high discount to NAV, a high dividend yield is likely to be a result of the factors that drive NAV discount rather than an explanatory per se. Likewise, the risk of the company as 
measure by the three year beta (BET3Y) is also significant. The co-efficient has expected sign and it is clear that higher systematic risk is associated with higher discounts. Other indicators of good performance such as annual returns and return on equity (ROE) have significant explanatory power and the expected negative signs. As expected, they indicate that the better the historic performance, the lower the discount to NAV.

\section{Conclusion}

This is not the final word on UK property company discounts, indeed it can be seen only as a small contribution into possible explanations. As we can see from the research, the property company discounts have been very variable in recent years but only for some companies. It is likely that some of the volatility in the discounts is caused by the decisions being made by the Boards in preparation for the conversion to UK REITs that are likely to be established in the next two years. But these decisions are rarely clearly revealed in the accounting data and despite our collecting information about the corporate governance of each company, that information shed little light onto the variation in discounts. 


\section{Bibliography}

Adams, A. and Venmore-Rowland, P. (1989) 'Property share valuation', Journal of Property Valuation 8(2):127-142, Winter 1989/90.

Barkham, R. J. and Geltner, D. M. (1995) 'Price Discovery and Efficiency in British and American Property Markets’, Real Estate Economics 23(1):21-44, 1995.

Barkham, R.J. and Purdy, D. E. (1992) Property Company Financial Reporting: Potential Weaknesses, Journal of Property Investment and Valuation 11(2):133-144, 1992/1993.

Barkham, R. J. (1997) 'The Financial Structure and Ethos of Property Companies: An Empirical Analysis of the Influence of Company Type', Construction Management \& Economics, Routledge, Volume 15, Number 5 / September 1, 441 - 456

Baum, A. (1995) 'Can Foreign Real Estate Investment be Successful', Real Estate Finance 12(1):81-89.

Capozza, D. R. and Lee, S. (1996) 'Portfolio characteristics and net asset values in REITs’, Canadian Journal of Economics, 29(2):520-526.

Corgell, J. B., Mcintosh, W. and Ott, S. H. (1995) 'Real Estate Investment Trusts: A Review of the Financial Economics Literature, Journal of Real Estate Literature 3:1343.

Currie, D. and Scott, A. (1991) The Place of Commercial Property in the UK Economy, London Business School, London, January 1991.

Cuthbertson, K. (1996), Quantitative Financial Economics, John Wiley and Sons, Chichester (UK) and elsewhere.

De Long, J.B., Shleifer, A., Summers, L.H. and Waldmann, R.J. (1990) 'Noise trader risk in financial markets, Journal of Political Economy, 98:703-738.

DTZ Debenham Thorpe (1995) Money into Property, London.

Enders, W. (1995) Applied Economic Time Series, John Wiley \& Sons, Inc., New York.

Gau, G. W. (1987) 'Efficient Real Estate Markets: Paradox or Paradigm?’ AREUEA Journal, 15(2):1-12.

Goebel, P. R. and Ma, C. K. (1993) 'Stock Returns and Business Performance in REITs’ working paper, Texas Tech University. 
Gyuorko, J. and Keim, D.B. (1992) 'What Does the Stock Market Tell Us About Real Estate Returns’, AREUEA Journal, 20(3):98-109.

Hirschman, A. O. (1964), The Paternity of an Index, American Economic Review, 54, 761.

Johansen, S. (1991) 'Estimation and Hypothesis Testing of Cointegration Vectors in Gaussian Vector Autoregressive Models’, Econometrica, 50, 1551-1580

Kirman, A.P. (1993) 'Ants, Rationality, and Recruitment', Quarterly Journal of Economics 108(1):137-156.

Kyle, A.S. (1985) 'Continuous Auctions and Inside Trading’ Econometrica, 53:131535.

Lee, C.M.C., Shleifer, A. and Thaler, R.H. (1991) 'Investor Sentiment and the Closed-End Fund Puzzle’, Journal of Finance XLVI (1):75-109, March.

Liu, C. H. and Mei, J. (1992) 'The Predictability of Returns on Equity REITs and Their Co-movement With Other Assets' Journal of Real Estate Finance and Economics 5(4):401-418.

Malkiel, B.G. (1995) 'The Structure of Closed-End Fund Discounts Revisited', The Journal of Portfolio Management, 32-38, Summer.

Sahi, W. (1996) The initial performance of IPOs of UK property and investment companies, Submitted for the degree of M.Sc. Real Estate, University of Reading.

Shleifer, A. and Summers, L.H. (1990) 'The Noise Trader Approach to Finance', Journal of Economic Perspectives, 4(2):19-33.

Shiller, R. J. (1989), Market Volatility, MIT Press, Cambridge, Massachusetts.

Shiller, R. J. (1990) 'Speculative Prices and Popular Models', Journal of Economic Perspectives, 4(2):55-65.

Schliefer, A. and Vishny, R.W. (1990) 'Equilibrium Short Horizons of Investors and Firms’, American Economic Review Papers and Proceedings, 80(2):148-153.

S.G. Warburg (1995) Review 1994 and Prospects for 1995, S.G Warburg Securities Ltd., 1 Finsbury Avenue, London, EC2M 2PA.

S.G. Warburg (1994) Review 1993 and Prospects for 1994, S.G Warburg Securities Ltd., 1 Finsbury Avenue, London, EC2M 2PA.

S.G. Warburg (1993) Review 1993 and Prospects for 1994, S.G Warburg Securities Ltd., 1 Finsbury Avenue, London, EC2M 2PA.

Scott P. (1996), The Property Masters-A History of the British Commercial Property Sector, E \& F Spon, London. 
Ward, C.W.R. and Henry, O. (1995) 'Do we need property to invest in property', Proceedings of 'The Cutting Edge' property research conference of the Royal Institution of Chartered Surveyors, held on 1-2 September 1995 at the University of Aberdeen.

White, H. (1980) A Heteroskedasticity-Consistent Covariance Matrix Estimator and a Direct Test for Heteroskedasticity', Econometrica 48:55-68 


\section{Appendix 1: Property Companies}

\begin{tabular}{|c|c|c|c|}
\hline Company & Market Cap (£m) & $\begin{array}{c}\text { Turnover } \\
(£ \mathrm{~m})\end{array}$ & $\begin{array}{c}\text { Average no. } \\
\text { Employees } \\
\end{array}$ \\
\hline Ashtenne Holdings & 138.05 & 34.83 & 198 \\
\hline British Land Co & $4,372.00$ & 497.70 & 701 \\
\hline Brixton & 879.22 & 98.30 & 39 \\
\hline Capital \& Regional & 419.73 & 39.46 & 231 \\
\hline CLS Holdings & 314.45 & 69.30 & 178 \\
\hline Derwent Valley Holdings & 539.07 & 47.90 & 24 \\
\hline Development Securities & 146.30 & 32.24 & 58 \\
\hline Freeport & 149.08 & 16.26 & 355 \\
\hline Great Portland Estates & 527.23 & 63.80 & 41 \\
\hline Hammerson & $2,195.00$ & 223.80 & 218 \\
\hline Helical Bar & 285.30 & 54.57 & 18 \\
\hline Land Securities Group & $6,197.82$ & $1,285.80$ & 1,677 \\
\hline Liberty International & 2,893.54 & 362.10 & 795 \\
\hline London Merchant Securities & 670.73 & 60.24 & 81 \\
\hline Marylebone Warwick Balfour Group & 79.68 & 227.29 & 1,666 \\
\hline Minerva & 469.35 & 61.44 & 30 \\
\hline NHP & 534.10 & 171.89 & 6,128 \\
\hline Pillar Property & 652.13 & 32.20 & 35 \\
\hline Quintain Estates \& Development & 660.49 & 60.48 & 170 \\
\hline Shaftesbury & 459.41 & 41.44 & 12 \\
\hline Slough Estates & $2,002.39$ & 325.90 & 559 \\
\hline St Modwen Properties & 384.06 & 122.78 & 200 \\
\hline Tops Estates & 165.09 & 29.59 & 15 \\
\hline Town Centre Securities & 183.17 & 24.59 & 64 \\
\hline Warner Estate Holdings & 249.17 & 44.37 & 59 \\
\hline Workspace Group & 354.95 & 51.07 & 145 \\
\hline Average & 996.98 & 156.90 & 527 \\
\hline Total & $25,921.51$ & $4,079.34$ & 13,697 \\
\hline
\end{tabular}




\section{Appendix 2: End of fiscal year}

\begin{tabular}{lr}
\hline 31st March & 10 \\
30th June & 4 \\
30th September & 2 \\
30th November & 1 \\
31st December & 9 \\
\hline \hline
\end{tabular}

Company

End of fiscal Year

Ashtenne Holdings PLC $\quad 31 / 12$

British Land Co PLC 31/3

Brixton PLC $\quad 31 / 12$

Capital \& Regional PLC $\quad 31 / 12$

CLS Holdings PLC $\quad 31 / 12$

Derwent Valley Holdings PLC $\quad 31 / 12$

Development Securities PLC 31/12

Freeport PLC $\quad 30 / 6$

Great Portland Estates PLC 31/3

Hammerson PLC 31/12

Helical Bar PLC 31/3

Land Securities Group PLC 31/3

Liberty International PLC 31/12

London Merchant Securities PLC 31/3

Marylebone Warwick Balfour Group PLC 30/6

$\begin{array}{ll}\text { Minerva PLC } & 30 / 6\end{array}$

NHP PLC $\quad 30 / 9$

Pillar Property PLC $\quad 31 / 3$

Quintain Estates \& Development PLC 31/3

Shaftesbury PLC 30/9

Slough Estates PLC $\quad 31 / 12$

St Modwen Properties PLC 30/11

Tops Estates PLC $\quad 31 / 3$

Town Centre Securities PLC 30/6

Warner Estate Holdings PLC 31/3

Workspace Group PLC $31 / 3$ 


\section{Appendix 3: Definition of Explanatory Variables}

All independent variables are defined as follows. Data from Balance Sheet and Income Statement, if not differently specified, are from Hemscott; data from stock markets, if not differently specified, are from DataStream Thomson Financial.

\section{ABRE12IN and ABRE36IN}

Those variables represent the abnormal return for shares in 12 or 36 month, calculated at the end of fiscal year. All return are calculated as geometric mean.

ABRE12IN = Share Mean return Last 12 Months - Mean return FTSE REAL ESTATE Index LAST 12 Month Total Return

ABRE36IN = Share Mean return Last 36 Months - Mean return FTSE REAL ESTATE Index LAST 36 Month Total Return

\section{ADMINRAT}

ADMINRAT is administrative costs as a percentage of the total value of the balance sheet and is calculated as:

ADMINRAT $=($ Sum of selling, general and administrative $) /$ Total Assets

\section{AUDITRAT}

AUDITRAT is audit costs as a percentage of the total value of the balance sheet and is calculated as:

AUDITRAT = (Sum of audit remuneration, other fees charged by auditors, political donations, charitable cash donations, non-cash comm. involvement, research and development) / Total Assets

\section{AVECOMP}

It is the natural logarithm of total compensation for all executive directors in the last available fiscal year. The higher, the more are paid the executive directors, independently from company’s size or value.

\section{BET3Y}

It is Beta coefficient calculated in a three years horizon on monthly base, using FTSE ALL SHARE total return index.

\section{CAPGEAR}

It is provided by DataStream Thomson Financial and represents leverage ratio.

CAPGEAR $=$ Total debt $\% /$ total capital

\section{COMHFDI}


It is the measures of diversification/concentration calculated as are Hirschman-Herfindahl $^{7}$ indices that are commonly used in industrial economics to measure monopoly power. It represent the concentration of compensations for executive directors. The higher the index, the higher is the compensation for most paid directors.

\section{DY}

Dividend yield ratio calculated as the last dividend on share price at the end of fiscal year.

\section{FIXTTAS}

It is the ratio between fixed asset and total asset. It represents the percentage of developments or properties held as inventory for trading purposes: their value is calculated as cost. A lower ratio indicates a low level of investments in fixed assets.

\section{LOGINST}

It is natural logarithmic of the total market value owned by shareholders with share's stake higher than 3\%. It is calculated using market value at the end of each fiscal year but maintaining share's stake as calculated at the end of 2003. This ratio indicates concentration of shares by institutional shareholder: high ratio means a strong control on the company.

\section{MEANRT1y}

It is the total return of stock, considering capital variation and dividend. It is calculated on annual base using monthly TOTAL RETURN DataStream:

LN(TRy1/TRy0)

It represents the absolute return of the company in the last year.

\section{NAVGEAR}

It is the ratio between Total Borrowings (Long term and Short term debts) and Net Asset Value. It is a measure of gearing.

\section{NOSALCOM}

It is the ratio between every kind or remuneration except fixed salary and the total salary received by executive directors. Numerator includes bonus, options and other benefits as reported by Hemscott. It refers only to the last year available (2003).

\footnotetext{
${ }^{7}$ The index first acquired the name of Orris Herfindahl from work on energy in the 1950s and that of Albert Hirschman from work on foreign trade patterns.
} 
The higher the ratio, the higher is the alignment of interest between executive directors and shareholders because their salary is more dependent on company's performance. Another interpretation is that best managers prefer to be paid according company's performance, so the higher the ratio the better the quality of management.

\section{ROE}

It is the traditional ratio return on equity. It is provided by DataStream.

\section{SIZEEV}

It represents the size of the firm as market total asset value: it is calculating as market value of equity plus value of debt.

LN (Market Value + Total Debt)

\section{SIZEMV}

It represents the size of the firm as market value of equity:

LN (Market Value)

\section{SIZETA}

It represents the size of the firm as total asset value:

LN (Total Asset) 
Appendix 4: Principal components analysis

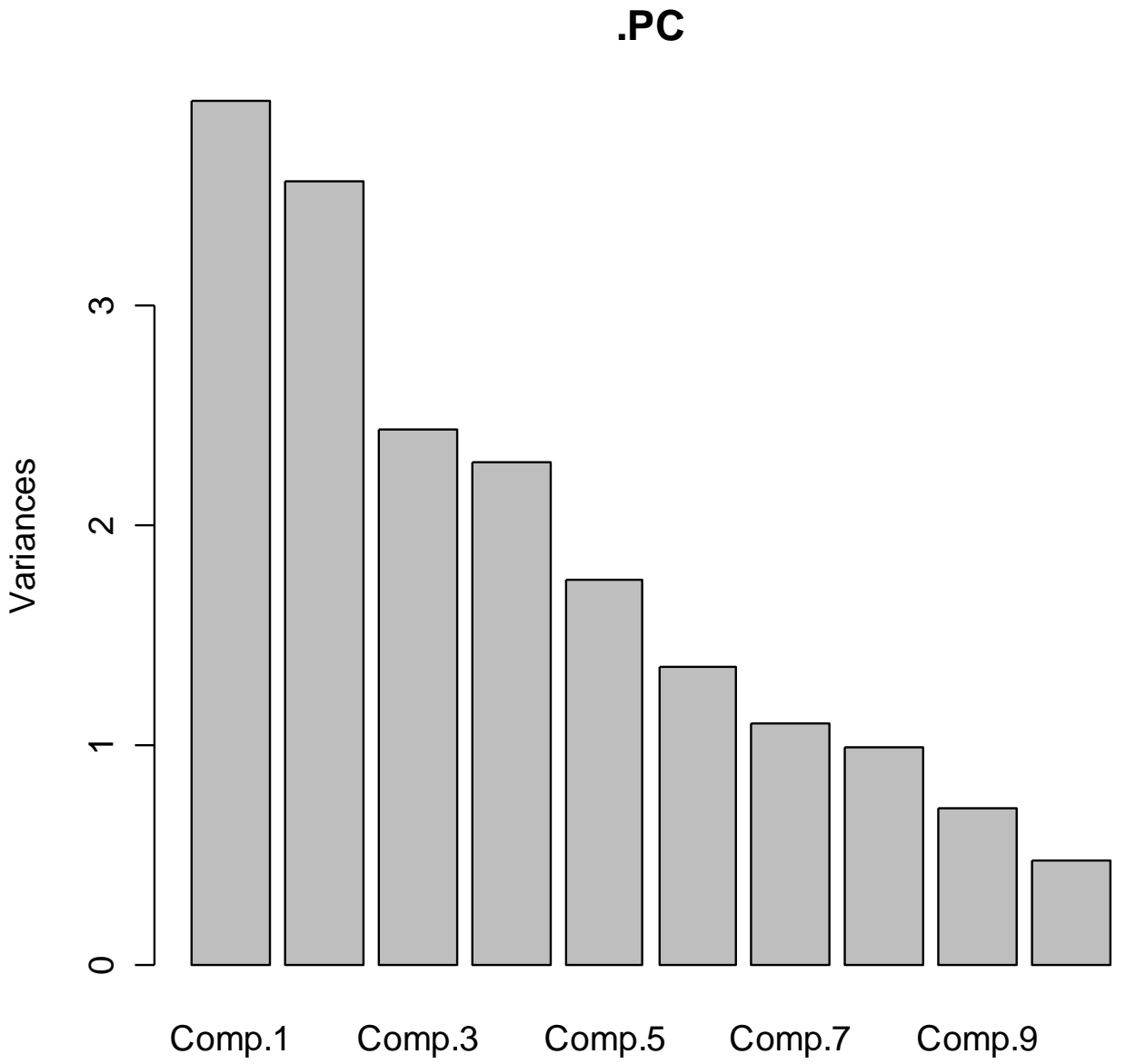

